\title{
Cost benefit Analysis Between Solar-Powered and Diesel Fuel-Fed Pumps of the National Irrigation Administration Upper Pampanga River Integrated Irrigation Systems
}

\author{
Christian Emmanuel Bencalo ${ }^{1}$, Rosalie D. Dela $\mathrm{Cruz}^{2}$, Debbie Rose Violago ${ }^{3}$, Merlin B. \\ Magtalas $^{4}$, Catherine S. Aquino ${ }^{5}$, Mercedes D. Santos, Ph.D. ${ }^{6}$ \\ ${ }^{1}$ Data Encoder, NIA UPRIIS \\ ${ }^{2}$ AECC General Manager, ASKI Group of Companies (AGC) Inc. \\ ${ }^{3}$ Compliance Officer, Alalay sa Kaunlaran (ASKI) Mutual Benefit Association, Inc. \\ ${ }^{4}$ Teacher III, Honorato C. Perez, Sr. Memorial Science High School, Department of Education, School Division of Cabanatuan City \\ ${ }^{5}$ Teacher II, Cristina David Pascual National High School, Department of Education, School Division of Gapan City \\ ${ }^{6}$ Business Administration Department, NEUST
}

Received: 19 Dec 2021; Received in revised form: 10 Feb 2022; Accepted: 20 Feb 2022; Available online: 28 Feb 2022

\begin{abstract}
This study described the profitability of the National Irrigation Administration- Upper Pampanga River Integrated Irrigation Systems NIA-UPRIIS' newly inaugurated solar-powered pumps in the Philippines. The researchers utilized the descriptive research design using the questionnaire technique to gather the necessary information. Engineers from NIA-UPRIIS Division IV were the respondents of the study. The researchers discovered that the project was profitable with cumulative estimated savings of Php 277,028,649.18. Moreover, the project resulted in reduced noise pollution which would have been generated by diesel fuel-fed generators. This has also reduced the gas emission from using the conventional method. The researchers suggest that more solar-powered projects be installed by the said agency in all its irrigation projects as this would result in big savings, while sparing some funds which can be used for other purposes.
\end{abstract}

Keywords - National Irrigation Administration, solar-powered pumps efficiency, savings, profitability.

\section{INTRODUCTION}

The National Irrigation Administration (NIA) is a government-owned and controlled corporation primarily responsible for irrigation development and management. "It was created under Republic Act (RA) 3601 on 22 June 1963. Its charter was amended by Presidential Decree (PD) 552 on 11 September 1974 and PD 1702 on 17 July 1980. Both increased the capitalization and broadened the authority of the Agency".

Upper Pampanga River Integrated Irrigation Systems (UPRIIS) is one of the government agencies under the National Irrigation Administration with the main base of operations located at Maharlika Highway, Cabanatuan City, Nueva Ecija, Philippines. It all started in May 1969 when Republic Act 5499 or the Upper Pampanga River

This article can be downloaded from here: $w w w . i j a e m s . c o m$
Project Act was approved by the Philippine Congress. The act authorized the construction of the Pantabangan Dam and its related structures and facilities and the approval of local counterpart funds. The Upper Pampanga River Project became officially known as the Upper Pampanga River Integrated Irrigation Systems. The provinces covered by UPRIIS consist mostly of the whole Nueva Ecija Province and parts of Pampanga, Bulacan, and Tarlac. As of Calendar Year 2015, UPRIIS serves 119,216.49 hectares which comprise of 4 Provinces, 23 Municipalities, 5 Cities, and 452 Barangay. The main source of water supply for UPRIIS is the Pantabangan Dam with a reservoir area of 8,420 hectares. A total of about 3 billion cubic meters of water can be stored in the reservoir. Aside from providing irrigation and flood 
control, the Pantabangan Dam also generates electricity that supplies power to the different provinces of the region through the Pantabangan and Masiway hydroelectric power plants.

However, with the prediction of fossil fuel depletion, many alternative sources of energy have been in development for the past few years were considered by NIA-UPRIIS. One such alternative energy source is solar energy. With it being harnessed from the sun it is renewable, free from the worry of future depletion and since it does not result in the release of harmful gases into the atmosphere, it is also environmentally friendly. Hence, NIA-UPRIIS has inaugurated solar-powered pumps into their irrigation system in July of 2021.

They have built two new solar powered pump projects in San Isidro and Penaranda, Nueva Ecija. "The Peñaranda Solar Powered Pump Irrigation Project, whose main water source comes from the Penaranda Dam through PENRIS Main Canal, is a P20.461-M project that is expected to provide reliable and proficient irrigation water supply in its 228.878-hectare service area located in Barangays Poblacion I, Poblacion Il, Santo Tomas in Penaranda, and Pambuan, Gapan City, benefitting a total of 114 farmer members of Penaranda IA. The San Isidro Solar Powered Pump Project, on the other hand, is situated in Brgy. Pulo, San Isidro, Nueva Ecija. With a total project cost of PI 7,780.519.47, this project will benefit 159 farmerbeneficiaries and their families in 323.2762-hectare agricultural lands, covering the Barangays Pulo and Mangga in San Isidro, Nueva Ecija. Its main water source

Project Specifications for the San Isidro and Peñaranda, Nueva Ecija, Philippines Solar-Powered Pumps

Table 1. Construction of Solar-Powered Pump San Isidro Project Profile

\begin{tabular}{|c|c|}
\hline Project Title & Improvement of Irrigation Facilities \\
\hline Location & Brgy. Pulo, San Isidro, Nueva Ecija \\
\hline Contract Description & $\begin{array}{l}\text { PENRIS/Construction of Solar Powered Pump@ } \\
\text { San Isidro }\end{array}$ \\
\hline Water Source & Malimba Creek \\
\hline Barangay Covered & $\begin{array}{l}\text { Barangays Pulo and Mangga, San Isidro, Nueva } \\
\text { Ecija }\end{array}$ \\
\hline Service Area & 323.2762 ha \\
\hline No. of Farmer Beneficiaries & 159 farmers \\
\hline Total Project Cost & P $17,780,519.47$ \\
\hline Coordinates of Pump Site & $\begin{array}{l}\text { Site } 1 \\
\text { Latitude: } 15.232653^{0} \\
\text { Longitude: } 120.936101^{0} \\
\text { Site } 2\end{array}$ \\
\hline
\end{tabular}

This article can be downloaded from here: www.ijaems.com is Malimba Creek" (Nocum, 2021). With this transition to solar energy, the researchers as Nueva Ecija University of Science and Technology Master of Business Administration students explore the profitability and feasibility of the two NIA-UPRIIS' newly-inaugurated solar-powered pumps. The findings of this study aims to compare the use of solar-powered pump as against the conventional diesel fuel-fed pump in terms of installation and maintenance costs.

\section{METHODOLOGY}

The researchers utilized the descriptive research design using the survey questionnaire to gather the necessary information. According to Dr. Y.P. Aggarwal (2008) as cited by Balaria (2012) and Garcia \& Subia (2019) "descriptive research is devoted to the gathering of information about prevailing conditions or situations for the purpose of description and interpretation". Hence, this study described the profitability of NIA-UPRIIS' newly inaugurated solar-powered pumps, the costs associated with this project included. Engineers from NIA-UPRIIS Division IV served as respondents of the study. The contents of the instrument consisted of the costs of operating and maintaining the solar-powered pumps as well as their benefits and drawbacks. These data were needed to validate the claims made by those interviewed. Documentary evidence such as financial statements were also requested from the concerned offices. 


\begin{tabular}{|c|c|}
\hline & $\begin{array}{l}\text { Latitude: } 15.22797^{0} \\
\text { Longitude: } 120.92979^{0}\end{array}$ \\
\hline Nature of Project & Water Pumping using Renewable Energy \\
\hline Irrigation Facilities & 1-Sub Lateral \\
\hline Irrigation Association & Malimba-Bantog-Manggahan IA \\
\hline Length of Canal & \\
\hline Lateral D-6a & $3+964-6+000(2.036 \mathrm{KM})$ \\
\hline Technical Specifications & \\
\hline Solar Panel & 90,390 watts of system capacity \\
\hline No. of Solar Panels & $\begin{array}{l}228 \text { pieces of } 1 \mathrm{~m} \times 2 \mathrm{~m} \text { solar panel frame ( } 395 \text { watts } \\
\text { each) }\end{array}$ \\
\hline Orientation of Solar Panels & $11^{0}$ inclination facing south \\
\hline Solar Panel Specifications & $\begin{array}{l}\text { Type: Monocrystalline Silicone } \\
\text { Power Rating: } 85 \mathrm{w} / 18 \mathrm{w} \\
\text { Features: Dust or Sandstorm proof } \\
\text { Lifetime: } 25 \text { years } \\
\text { Warranty: } 10 y e a r s\end{array}$ \\
\hline
\end{tabular}

Table 2. Construction of Solar-Powered Pump Peñaranda Project Profile

\begin{tabular}{|c|c|}
\hline Project Title & Improvement of Irrigation Facilities \\
\hline Location & Brgy. San Josef, Peñaranda, Nueva Ecija \\
\hline Contract Description & PENRIS/Construction of Solar Powered Pump @ Peñaranda \\
\hline Water Source & Peñaranda Dam through PENRIS Main Canal \\
\hline Barangay Covered & $\begin{array}{l}\text { Barangays Poblacion I, Poblacion II, Santo Tomas in Peñaranda and } \\
\text { Pambuan in Gapan City, Nueva Ecija }\end{array}$ \\
\hline Service Area & 228.878 ha \\
\hline No. of Farmer Beneficiaries & 114 farmers \\
\hline Total Project Cost & Р20,461,285.99 \\
\hline Coordinates of Pump Site & $\begin{array}{l}\text { Latitude: } 15.345400^{0} \\
\text { Longitude: } 121.000766^{0}\end{array}$ \\
\hline Nature of Project & Water Pumping using Renewable Energy (Solar) \\
\hline Irrigation Facilities & $\begin{array}{l}\text { 1-Lateral Canal } \\
\text { 1-Sub Lateral }\end{array}$ \\
\hline Irrigation Association & Peñaranda IA \\
\hline \multicolumn{2}{|l|}{ Length of Canal } \\
\hline Lateral A & $0+000-2+577(2.577 \mathrm{KM})$ \\
\hline Lateral A-1 & $0+000-1+866(1.866 \mathrm{KM})$ \\
\hline \multicolumn{2}{|l|}{ Technical Specifications } \\
\hline Solar Panel & 90,390 watts of system capacity \\
\hline
\end{tabular}




\begin{tabular}{|c|c|}
\hline No. of Solar Panels & 228 pieces of $1 \mathrm{~m} \times 2 \mathrm{~m}$ solar panel frame ( 395 watts each) \\
\hline Orientation of Solar Panels & $11^{0}$ inclination facing south \\
\hline Solar Panel Specifications & $\begin{array}{l}\text { Type: Monocrystalline Silicone } \\
\text { Power Rating: } 85 \mathrm{w} / 18 \mathrm{w} \\
\text { Features: Dust or Sandstorm proof } \\
\text { Lifetime: } 25 \text { years } \\
\text { Warranty: 10years }\end{array}$ \\
\hline
\end{tabular}

\section{RESULTS AND DISCUSSION}

Based on the gathered data, the service area of the Peñaranda solar-powered pump covers 228.878 hectares which is equivalent to $926,236.40$ square meters, whereas the San Isidro solar-powered pump's service area is 323.2762 hectares that can be translated to $1,308,252.37$ square meters. The total service area for the two pumps is 2,234,488,77 square meters. Each of the solar power pump installations can provide 90,390 watts or a combined capacity of 180,780 watts or $180.78 \mathrm{~kW}$ that can be considered adequate for the irrigation service area.

The two solar-powered pump projects have a total cost of Php 38,241,805.46 broken down as Php 20,461,285.99 for the Peñaranda project and Php 17,780,519.47 for the San Isidro project. A quick search on Google for a $225 \mathrm{kva}$ (equal to $180 \mathrm{kw}$ ) diesel-fueled generator shows a result from Alibaba.com for one has a price of Php 661,720.10. Two generators will be required as there are two service areas to be inaugurated, thus bringing the amount to $\mathrm{Php}$ $1,323,440.20$ (Twice the mentioned amount of $661,720.10)$

"Diesel generators can last for at least $\mathbf{1 5 , 0 0 0}$ hours to a maximum of $\mathbf{5 0 , 0 0 0}$ hours before needing a maintenance. Ultimately, the life expectancy of a generator will depend on factors such as generator sizing and preventive maintenance practices" (The life Expectancy of Your Diesel Generator, 2020). The above data point that the general average life of a diesel generator is 32,500 hours (average of 15,000 hours and 50,000 hours). In comparison, the total number of hours in 25 years, the useful life of the solar power generators is approximately $\mathbf{2 1 9 , 0 0 0}$ hours ( 24 hours a day, 365 days a year, for 25 years, excluding additional one day during leap year). This means that the diesel- powered generators would require major servicing 6 times, rounded from 5.74 times ((219,000/32,500)-1), within the span of 25 years.

"The average operations and maintenance cost for diesel reciprocating engine-driven generators is \$0.005-\$0.010 per kWh, according to the GTI. For natural gas generators, the average cost is $\$ 0.007-\$ 0.015$ per $\mathrm{kWh"}$
(Onsite Options, 2002). Using a conversion ratio of Php 50 to a dollar at the current rate, this can be translated to Php 0.375 per kilowatt-hour. With a generator of $180 \mathrm{~kW}$ capacity, the average maintenance cost is Php 12,187 each time (average of $0.25-0.50 * 32,500$ hours of useful life) before needing servicing. Since the major servicing is expected to occur 6 times within 25 years, the cumulative cost amounts to Php 73,125.

With the assumption that the diesel-fed generator would run all day, as the solar power pumps would do, the total fuel volume for 25 years would amount to $\mathbf{1 , 8 2 3 , 1 7 5}$ gallons (219,000 hours with 16.7 gallons used per hour). "Diesel prices: We show prices for the Philippines from 09-Aug-2021 to 15-Nov-2021. The average value for the Philippines during that period was Php $\mathbf{4 5 . 5 2}$ with a minimum of 41.35 Philippine Peso on 27-Sep-2021 and a maximum of 52.27 Philippine Peso on 15Nov-2021. For comparison, the average price of diesel in the world for this period is 75.51 Philippine Peso" (Philippine Diesel Prices, 2021). Global Petrol Prices.com presents Diesel prices in the Philippines to be 45.52 pesos per liter. A gallon is approximately equal to 3.79 liters. Thus, 1,823 , 175 gallons is equivalent to $6,909,833.25$ liters. The total fuel cost for the next 25 years will be Php 314,535,609.54 
Table 3. Cost-Benefit Analysis Between Solar-Powered and Diesel-Powered Pumps

\begin{tabular}{|c|c|c|c|c|}
\hline & $\begin{array}{c}\text { Initial Cost } \\
(\mathrm{Php})\end{array}$ & $\begin{array}{c}\text { Subsequent Fuel Cost } \\
(\mathrm{Php})\end{array}$ & $\begin{array}{c}\text { Overhaul Cost } \\
\text { (Php) }\end{array}$ & $\begin{array}{c}\text { Cumulative } \\
\text { maintenance cost for } \\
25 \text { years (Php) }\end{array}$ \\
\hline Solar Power Pump & $38,241,805.46$ & - & - & - \\
\hline Diesel Powered Pump & $1,323,440.20$ & $314,535,609.54$ & $73,125.00$ & $315,932,174.74$ \\
\hline Difference & & & & $\mathbf{2 7 7 , 0 2 8 , 6 4 9 . 1 8}$ \\
\hline
\end{tabular}

In comparison, solar-powered pump can be considered more efficient and cost-effective compared to dieselpowered pump. The figure does not include other costs for implementing a diesel-powered pump irrigation system, such as the irrigation lines and laterals, only making projections on the generator price, repair and fuel costs. Although the cost in installing solar-powered pump can be 29 times higher than diesel-powered pump, long term considerations in maintenance cost can save the Philippine government some Php 277,028,649.18.

\section{CONCLUSIONS AND RECOMMENDATIONS}

Based on the findings of the study, the researchers concluded that the use of solar-powered pump is more efficient and cost-effective than the use of diesel-powered pump. It is also estimated a savings of approximately Php 277,028,649.18. Furthermore, solar-powered pump reduces noise pollution and eliminates the harmful effects of gas emission from diesel fuel-fed generators. The researchers recommend that more solar-powered pumps be installed by the agency for all its irrigation projects as this would result in big savings in the long term for the Philippine government.

\section{REFERENCES}

[1] Approximate Diesel Fuel Consumption Chart. Generator Source.

[2] https://www.generatorsource.com/Diesel_FuelConsumptio n.aspx ?fbclid=lwAROpojEZiKIWJ-Pcbi17rKuLZCeSDd519J2qS3AwaTG8s5A4ZjkaTZMQc

[3] Are Solar Panels Worth It in 2021? (2021, January 4). Unbound Solar. https.//unboundsolar.com/blog/are-solarpanels-worth-it

[4] Benefits of Solar Energy. (2018, May 27). Solaren Power Philippines. https://solaren-power.com/benefits-of-solarenergy-solar-panels-philippines/

[5] Garcia, Mary Grace G., and Subia, Gener, S. (2019). High School Athletes: Their Motivation, Study Habits, Selfdiscipline, and Academic Performance. International Journal of Physical Education, Sports and Health 2019; 6(1): 86-90.
[6] Jiangsu Jianghao Factory Diesel Generator 225kva for Sale. Alibaba.com. https://www.alibaba.com/productdetail/Jiangsu-Jianghao-factory-dieselgenerator-225 62377245847.html?mark=google_shopping\&seo=1

[7] Nocum, EA. (2021, July 27). NIA INAUGURATES TWO NEWLY COMPLETED SOLAR-POWERED PUMP IRRIGATION PROJECTS INNUEVA ECIJA. NIAUPRIIS Website. http://upriis.nia.gov.ph/?q=content/niainaugurates-two-newly-completedsolar-powered-pumpirrigation-projects-nueva-ecija

[8] Onsite Options (2002, March 1). Facilitiesnet. https://www.facilitiesnet.com/powercommunication/article/ Onsite-Options-1679.

[9] Philippines Diesel prices, 15-Nov-2021. GlobalPetrolPrices.com. https://www.globalpetrolprices.com/Philippines/diesel_pric es/

[10] Salaria N. Meaning of the Term-Descriptive Survey

[11] Research Method. International Journal of Physical Education, Sports and Health Transformations in Business Management. (IJTBM), 2012, 1(6).

[12] The Beneits of Solar Water Pumps Systems. Advanced Power Inc. https://solarpumps.com/articles/2018/thebenefits-of-solar-water-pump systems?fbclid=IwAR2Nhyj822MiTXjTJNQ5DhoXfw37g usi9qigJfXxGFIvTH3g2ppxBSJr2_g

[13] The Life Expectancy of Your Diesel Generator (2020, August 21). ReactPower Solutions. https.//www.reactpower.corwblog/the-lifeexpectancyof-your-diesel-generator/ 